Bull. Fac. Agric., Cairo Univ.,58(2007):222-232.

\title{
IRRIGATION SCHEDULING OF SOME MAIZE CULTIVARS USING CLASS A PAN EVAPORATION IN NORTH DELTA, EGYPT
}

(Received:16.1.2007)

\author{
By \\ A.Z. El-Bably
}

Soils, Water and Environment Research Institute, Agricultural Research Center, Giza, Egypt

\begin{abstract}
Two field experiments were carried out during two summer seasons of (2005 and 2006) at Sakha Agricultural Research Station, Kafr El-Sheikh Governorate to investigate irrigation scheduling of maize cultivars using class A pan evaporation in North Delta, Egypt. Irrigation water was applied at 1.2, 1.0 and 0.8 of accumulative pan evaporation (A.P.E), while maize cultivars used were hybrid single crosses (S.C.) 10, 122 and 124. The results showed that irrigation scheduling at 1.2 of accumulative pan evaporation (A.P.E) significantly increased plant height by $4.4 \%$, ear length by $4.6 \%$, number of rows/ear by $16.7 \%$, number of grains/row by $7.3 \%, 100$-grain weight by $6.6 \%$, yield of plant by $17.1 \%$ and grain yield./fed. by $18.1 \%$ compared to irrigation at 0.8 of A.P.E.Maize cv. S.C. 10 significantly surpassed maize cvs. S.C. 122 and S.C. 124 in the mean values of plant height, ear length, number of grains/row, 100-grain weight, yield of plant and grains yield/fed. However, maize cv. S.C. 122 was superior in the number of rows/ear to maize cvs. S.C. 10 and S.C. 124.Seasonal water use values were $57.74,52.16$ and $47.60 \mathrm{~cm}$ for irrigated maize plants at 1.2 , 1.0 and 0.8 of A.P.E., respectively. Irrigation at 1.2 of A.P.E. resulted in higher amount of irrigation water applied to be $74.3 \mathrm{~cm}$ distributed on 7 irrigations, followed by irrigation at 1.0 to be $67.2 \mathrm{~cm}$ distributed on 6 ones, and irrigation at 0.8 of A.P.E. was $57.1 \mathrm{~cm}$ distributed on 5 ones. It was also found that the intervals of irrigation were $21,14,14,13,14$ and 16 days for irrigation at 1.2 of A.P.E. and 21, 16, 18, 18 and 19 days for irrigation at 1.0 of A.P.E. and 21, 21, 22 and 25 days for irrigation at 0.8 of A.P.E., respectively. Lower frequent irrigation due to irrigation at 0.8 of APE resulted in a significantly higher water use efficiencies compared to the other two irrigation treatments. Maize cv. S.C. 10 significantly increased water use efficiencies compared to maize cvs. S.C. 122 and 124 due to higher yielding. Most of the consumed water was removed from the upper layer $(0-15 \mathrm{~cm})$ of the soil profile because of root concentrations and its activity. At the same time, soil moisture extraction pattern by maize roots was not affected by the cultivars. Linear equation slopes between irrigation water applied and grain yield, water use efficiency and water utilization efficiency were 44.0, -0.20 and -0.41 , respectively. It was concluded that irrigation scheduling in maize based on 1.2 of accumulative pan evaporation produced high yield in North Delta, Egypt.
\end{abstract}

Key words: irrigation scheduling, maize cultivars, soil moisture extraction pattern, water consumptive use, water requirements, water use efficiency.

\section{INTRODUCTION}

In Egypt, maize is a major cereal summer crop and it has a special importance because the national production is not enough to meet the increase of local demands. One of the important factors to increase crop production is a successful water management through when to irrigate and how much water amount applied each time.

Proper irrigating management demands application of water at the time of actual need of the crop with just enough water to wet the effective root zone depth. The interval between two irrigations should be as wide as possible to save irrigation water without any adverse effect on the growth and yield (Majumdar, 2002). Irrigation applied before the time of actual crop need encourages only losses of water through higher evapotranspiration and deep percolation. On the other hand, delayed irrigation causes plant water stress that depresses the growth activities and yield (Majumdar, 2002). Water stress all over maize growing season, or only at reproductive stage significantly reduced plant height, ear length, number of grains/row, number of grains/ ear and grain yield/fed. (Oraby et al., 2005). Mahfouz (2003) indicated that water stress (irrigation every 25 days) caused severe reduction in yield and yield components of ten hybrids. Grain yield of maize was significantly increased with the decrease in irrigation period (Kamara et al., 2003, 
Kefale and Ranamukhaarachchi 2004 and Ibrahim et al., 2005). El-Sabbagh et al.,(1997) found that irrigation at $80 \%$ of the field capacity gave the highest values of ear length, ear weight, number of kernel/row, 100-kernel weight and grain yield/feddan. They also found that the values of water consumptive use were $69.41,58.30$ and 46.68 $\mathrm{cm}$ for treatments irrigated at $80 \%, 65 \%$ and $50 \%$ of field capacity, respectively. Seif et al.,(2005) found that the highest yield was obtained when maize plants were irrigated at $40 \%$ of the available soil moisture depletion, whereas the lowest yield was recorded at $80 \%$ of the available soil moisture depletion. Mitu and Zamfir (2004) found that prolonged drought throughout the growth period resulted in higher yield losses (76-77\%) compared with partial drought experienced in the second part of maize growth (62-65\%) or in the first part of maize growth (26-30\%). Abdel Mawly and Zanouny (2005) found that the recommended evaporation pan coefficient (EPC) for scheduling irrigation was 1.0 for maize (hybrid $310 \mathrm{cv}$.) in Upper Egypt, Khalil (2001) and El-Atawy (2007) revealed that irrigation at 1.3 accumulative pan evaporation significantly recorded the highest grain yield and yield components of maize compared with 1.0 and 0.7 accumulative pan evaporation.

As for maize hybrids, Oraby et al., (2005) revealed that the single cross 10 significantly surpassed the other hybrids i.e. S.C. 10 and T.W.C.310 in plant height, number of grains/row, 100 -grain weight, and grain yield/fed. Single cross S.C. 10 was more sensitive to water stress during the late growth stage than S.C. 18 and T.W.C.310. Khalil (2001) revealed that the S.C. 10 cultivar, produced higher grain yield $(15.7 \%)$ and water consumption (452.5 mm water/season) compared to T.W.C. 310 (consumed $417 \mathrm{~mm}$ water/season). Seif et al.,(2005) showed that maize cultivar cv. S.C. 10 surpassed the other four cultivars (TWC310, Giza 2, S.C. 152 and T.W.C.352) in ear weight, ear length, number of grains per row, 100-grain weight, and grain yield.

\section{MATERIALS AND METHODS}

Two field experiments were conducted at Sakha Agricultural Research Station, Kafr El-Sheikh Governorate, during the two successive seasons of 2005 and 2006. A split-plot design with four replicates was used. The main plots were devoted to irrigation treatments i.e. $1.2,1.0$ and 0.8 of accumulative pan evaporation (A.P.E.) while subplots were assigned to maize cultivars i.e. hybrid single cross (S.C.) 10, 122 and 124. Sub-plot area was $42 \mathrm{~m}^{2}$ including 10 rows, $7 \mathrm{~m}$ long and $70 \mathrm{~cm}$ apart. Plots were isolated by ditches of $1.5 \mathrm{~m}$ in

Table (1): Sakha meteorological data of Agricultural Research Station during 2005 and 2006 seasons.

\begin{tabular}{|c|c|c|c|c|c|c|c|c|c|c|c|c|c|c|}
\hline \multirow{3}{*}{\begin{tabular}{|c|} 
Seasons \\
\\
Intervals \\
\end{tabular}} & \multicolumn{6}{|c|}{2005} & \multirow{3}{*}{\begin{tabular}{|c|} 
Pan \\
evapor- \\
ation \\
$(\mathrm{mm} / \mathrm{day})$ \\
\end{tabular}} & \multicolumn{6}{|c|}{2006} & \multirow{3}{*}{$\begin{array}{c}\text { Pan } \\
\text { evapor-ation } \\
(\mathrm{mm} / \text { day })\end{array}$} \\
\hline & \multicolumn{3}{|c|}{$\begin{array}{c}\text { Air temperature } \\
{ }^{\circ} \mathbf{C} \\
\end{array}$} & \multicolumn{3}{|c|}{$\begin{array}{c}\text { Relative humidity } \\
(\%)\end{array}$} & & \multicolumn{3}{|c|}{$\begin{array}{c}\text { Air temperature } \\
{ }^{\mathbf{0}} \mathbf{C} \\
\end{array}$} & \multicolumn{3}{|c|}{$\begin{array}{c}\text { Relative humidity } \\
(\%)\end{array}$} & \\
\hline & Max. & Min. & Mean & Max. & Min. & Mean & & Max. & Min. & Mean & Max. & Min. & Mean & \\
\hline $1-10 / 6$ & 30.8 & 16.2 & 23.8 & 80.1 & 45.0 & 62.6 & 7.24 & 33.2 & 16.5 & 24.9 & 69.0 & 46.0 & 57.5 & 8.40 \\
\hline $11-20 / 6$ & 32.0 & 18.0 & 25.0 & 80.4 & 43.0 & 61.7 & 8.13 & 29.5 & 15.9 & 22.7 & 79.0 & 46.0 & 62.5 & 8.08 \\
\hline $21-30 / 6$ & 31.7 & 18.4 & 25.1 & 86.0 & 53.0 & 69.5 & 8.00 & 32.7 & \begin{tabular}{|l|}
19.1 \\
\end{tabular} & 25.9 & 86.3 & 50.0 & 68.2 & 8.41 \\
\hline $1-10 / 7$ & 32.5 & 19.0 & 25.8 & 88.6 & 55.3 & 72.0 & 7.75 & 32.3 & 18.5 & 25.4 & 87.0 & 58.6 & 72.8 & 7.03 \\
\hline $11-20 / 7$ & 34.1 & 19.3 & 26.7 & 90.9 & 51.4 & 71.2 & 7.61 & 32.5 & 18.6 & 25.6 & 86.2 & 60.1 & 73.2 & 7.41 \\
\hline $21-31 / 7$ & 33.5 & 20.7 & 27.1 & 92.7 & 56.6 & 74.7 & 7.49 & 32.2 & 17.0 & 24.6 & 90.5 & 60.4 & 75.5 & 7.64 \\
\hline $1-10 / 8$ & 33.6 & 231.0 & 27.3 & 90.5 & 55.5 & 73.0 & 7.23 & 32.8 & 18.4 & 25.6 & 95.0 & 62.0 & 78.5 & 6.91 \\
\hline $11-20 / 8$ & 34.0 & 20.0 & 27.0 & 92.3 & 52.1 & 72.2 & 7.10 & 34.3 & 19.8 & 27.1 & 96.0 & 62.0 & 79.0 & 6.86 \\
\hline $21-31 / 8$ & 32.7 & 19.0 & 25.9 & 91.2 & 56.0 & 73.6 & 6.51 & 343 & \begin{tabular}{|l|}
19.6 \\
\end{tabular} & 27.0 & 93.0 & 58.0 & 75.5 & 6.25 \\
\hline $1-10 / 9$ & 31.0 & 17.6 & 24.3 & 85.7 & 53.7 & 69.7 & 6.60 & 32.7 & 16.5 & 24.6 & 85.0 & 56.0 & 70.5 & 6.19 \\
\hline $11-20 / 9$ & 33.0 & 20.4 & 26.7 & 90.5 & 53.3 & 71.9 & 6.43 & 33.0 & 17.0 & 25.0 & 91.4 & 49.0 & 70.2 & 6.10 \\
\hline $21-30 / 9$ & 32.5 & 17.0 & 24.8 & 86.0 & 53.6 & 69.8 & 6.27 & 33.0 & 16.5 & 24.8 & 85.0 & 53.0 & 69.0 & 5.54 \\
\hline $1-10 / 10$ & 30.2 & 16.0 & 23.1 & 81.0 & 55.0 & 68.0 & 43.96 & 31.2 & 14.5 & 22.9 & 82.0 & 52.0 & 67.0 & 6.15 \\
\hline $11-20 / 10$ & 28.1 & 13.7 & 20.9 & 81.0 & 55.0 & 68.0 & 4.58 & 31.0 & 14.7 & 22.9 & 76.0 & 51.0 & 63.5 & 4.56 \\
\hline $21-31 / 10$ & 26.0 & 13.4 & 19.7 & 74.2 & 51.4 & 62.8 & 4.62 & 28.3 & 12.2 & 20.3 & 78.0 & 51.0 & 64.5 & 3.79 \\
\hline
\end{tabular}


width to avoid lateral movement of water. Planting was in hills $30 \mathrm{~cm}$ apart, seeding rate was $15 \mathrm{~kg} / \mathrm{fed}$. Maize hybrid grains were planted in June $15^{\text {th }}$ and $13^{\text {th }}$ in 2005 and 2006 seasons, respectively. Plants were thinned to one plant per hill before the first irrigation. The preceding crop was clover in both seasons. Nitrogen fertilizer was added in the form of urea $(46.5 \% \mathrm{~N})$ at the rate of $120 \mathrm{~kg} \mathrm{~N} / \mathrm{fed}$. Phosphorus fertilizer was applied in the form of calcium superphosphate $15.5 \% \mathrm{P}_{2} \mathrm{O}_{5}$ at the rate of $30 \mathrm{~kg} \mathrm{P}_{2} \mathrm{O}_{5} / \mathrm{fed}$. during tillage operation. All recommended agricultural practices were followed through the growing seasons according to Ministry of Agriculture (2005). The soil of the experimental site was clayey in texture. The electrical conductivity of soil $(0-60 \mathrm{~cm}$ layer $)$, irrigation water, and $\mathrm{pH}$ of the soil in the saturated soil paste were $2.03 \mathrm{dS} / \mathrm{m}, 0.48 \mathrm{dS} / \mathrm{m}$ and 8.10 , respectively (Page, 1982). Water table level was $121 \mathrm{~cm}$ by using observation well.

Maize plants were harvested at 120 days from planting in both seasons. Ten guarded plants were randomly taken from the fourth inner rows to determine yield components. Grain yield was obtained from the central area of each plot $(1 / 300$ fed.) to avoid any border effect. Maize grain yield was adjusted to $15.5 \%$ moisture content. The following traits were measured i.e. plant height in $\mathrm{cm}$, ear length in $\mathrm{cm}$, number of rows/ear, number of grains/row, 100-grain weight in gm, yield of plant in gm, and grain yield in $\mathrm{kg} / \mathrm{fed}$.

Sakha meteorological station data, during 2005 and 2006 seasons, were recorded. Meteorological data having air temperature, relative humidity (\%), and pan evaporation from class A pan are presented in Table (1).

Data were subjected to the combined analysis as described by Snedecor and Cochran (1980). The treatment means were compared according to Duncan's multiple range test (Duncan, 1955).

\section{Soil-water relation:}

Soil moisture content was gravimetrically determined in soil samples taken from consecutive depths of $15 \mathrm{~cm}$ down to a depth of $60 \mathrm{~cm}$. Soil samples were also collected just before each irrigation, 48 hours after irrigation and at harvest time. Field capacity, permanent wilting point and bulk density were determined according to Klute (1986) to a depth of $60 \mathrm{~cm}$ (Table 2).

\section{Time of irrigation}

The available soil water was converted to water depth in mm (Table 2) and it was $116.5 \mathrm{~mm}$. At every irrigation, the equivalent amount of evaporation that can occur was estimated, while this amount of available soil water is being used. Irrigation was timed when accumulative pan

Table (2): Soil moisture constants for the experimental site.

\begin{tabular}{|c|c|c|c|c|c|}
\hline \multirow{2}{*}{$\begin{array}{c}\text { Soil } \\
\text { depth } \\
(\mathrm{cm})\end{array}$} & \multirow{2}{*}{$\begin{array}{c}\text { Field } \\
\text { capacity } \\
(\%)\end{array}$} & \multirow{2}{*}{$\begin{array}{c}\text { Wilting } \\
\text { point } \\
(\%)\end{array}$} & \multirow{2}{*}{$\begin{array}{r}\text { Bulk } \\
\text { density } \\
\left(\mathrm{g} / \mathrm{cm}^{3}\right) \\
\end{array}$} & \multicolumn{2}{|c|}{$\begin{array}{c}\text { Available soil } \\
\text { water }\end{array}$} \\
\hline & & & & $\%$ & $\mathbf{m m}$ \\
\hline $0-15$ & 46.52 & 25.71 & 1.10 & 20.81 & 34.34 \\
\hline $15-30$ & 40.13 & 23.90 & 1.16 & 16.23 & 28.24 \\
\hline $30-45$ & 37.20 & 22.32 & 1.21 & 14.88 & 27.01 \\
\hline $45-60$ & 34.16 & 20.59 & 1.32 & 13.57 & 26.87 \\
\hline
\end{tabular}

evaporation (A.P.E.) amounted to $116.5 \mathrm{~mm}$ for each treatment of 1.2, 1.0, and 0.8 of A.P.E. Scheduling of irrigation started after applying the first irrigation. Monthly accumulative pan evaporation (A.P.E) during 2005 and 2006 seasons is presented in Table (3).

\subsection{Irrigation water applied (IWA):}

Irrigation water was calculated by the summation of the daily records of class A pan evaporation. Submerged flow orifice with fixed dimension was used to measure the amount of water applied, as the following equation (Michael, 1978).

$$
\mathrm{Q}=\mathrm{CA} \sqrt{2 \mathrm{gh}}
$$

\section{Where:}

$\mathrm{Q}=$ discharge through orifice, $(1 / \mathrm{sec})$.

$\mathrm{C}=$ coefficient of discharge, $(0.61)$.

$\mathrm{A}=$ cross-sectional area of the orifice, $\mathrm{cm}^{2}$.

$\mathrm{g}=$ acceleration due to gravity, $\mathrm{cm} / \mathrm{sec}^{2}{ }^{2}$ (981 $\mathrm{cm} / \mathrm{sec}^{2}$ ).

$\mathrm{H}=$ pressure head, causing discharge through the orifice, $\mathrm{cm}$.

\subsection{Water consumptive use}

Water consumptive use was calculated using the following equation (Hansen et al., 1979).

$$
\mathrm{CU}=\sum_{i=1}^{\mathrm{i}=4} \mathrm{D}_{\mathrm{i}} * \mathrm{D}_{\mathrm{bi}} * \frac{\mathrm{PW}_{2}-\mathrm{PW}_{1}}{100}
$$

Where:

$\mathrm{CU}=$ water consumptive use $(\mathrm{cm})$ in the effective root zone $(60 \mathrm{~cm})$.

$\mathrm{D}_{\mathrm{i}} \quad=$ soil layer depth $(15 \mathrm{~cm})$.

$\mathrm{D}_{\mathrm{bi}}=$ soil bulk density, $\left(\mathrm{g} / \mathrm{cm}^{3}\right)$ for this depth.

$\mathrm{PW}_{1}=$ soil moisture percentage before irrigation.

$\mathrm{PW}_{2}=$ soil moisture percentage, 48 hours after irrigation.

I = number of soil layers $(15 \mathrm{~cm})$.

\subsection{Water use efficiency (WUE)}

It was calculated according to Jensen (1983).

$\mathrm{WUE}=\mathrm{Y} / \mathrm{CU}$

\section{Where:}


Table (3): Monthly accumulative pan evaporation (A.P.E) as affected by the irrigation treatments during 2005 and 2006 seasons.

\begin{tabular}{|c|c|c|c|c|c|c|c|c|}
\hline \multirow[b]{3}{*}{ Intervals of A.P.E. } & \multicolumn{4}{|c|}{2005} & \multicolumn{4}{|c|}{2006} \\
\hline & \multirow{2}{*}{$\begin{array}{c}\text { A.P.E. } \\
\text { mm }\end{array}$} & \multicolumn{3}{|c|}{ Irrigation at A.P.E. of } & \multirow{2}{*}{$\begin{array}{c}\text { A.P.E. } \\
\text { mm }\end{array}$} & \multicolumn{3}{|c|}{ Irrigation at A.P.E. of } \\
\hline & & 0.8 & 1.0 & 1.2 & & 0.8 & 1.0 & 1.2 \\
\hline $1-10 / 6$ & 72.4 & 57.9 & 72.4 & 86.9 & 84.0 & 67.2 & 84.0 & 100.8 \\
\hline $11-20 / 6$ & 81.3 & 65.0 & 81.3 & 97.6 & 80.1 & 64.1 & 80.1 & 96.1 \\
\hline $21-30 / 6$ & 79.3 & 63.4 & 79.3 & 95.5 & 84.1 & 67.3 & 84.1 & 100.9 \\
\hline Total & 233.3 & 186.3 & 233.0 & 280.0 & 248.2 & 198.6 & 248.2 & 297.8 \\
\hline $1-10 / 7$ & 77.5 & 62.0 & 77.5 & 93.0 & 70.3 & 56.2 & 70.3 & 84.4 \\
\hline $11-20 / 7$ & 76.1 & 60.9 & 76.1 & 91.3 & 74.1 & 59.3 & 74.1 & 88.9 \\
\hline $21-31 / 7$ & 74.9 & 59.9 & 74.9 & 89.9 & 76.4 & 61.1 & 76.4 & 91.7 \\
\hline Total & 228.5 & 182.8 & 228.5 & 274.2 & 220.8 & 176.6 & 220.8 & 265.0 \\
\hline $1-10 / 8$ & 72.3 & 57.8 & 72.3 & 86.8 & 69.1 & 55.3 & 69.1 & 82.9 \\
\hline $11-20 / 8$ & 71.0 & 56.8 & 71.0 & 85.2 & 68.6 & 54.9 & 68.6 & 82.3 \\
\hline $21-31 / 8$ & 65.1 & 52.1 & 65.1 & 78.1 & 62.5 & 50.0 & 62.5 & 75.0 \\
\hline Total & 208.4 & 166.7 & 208.4 & 250.1 & 200.2 & 160.2 & 200.2 & 240.2 \\
\hline $1-10 / 9$ & 66.0 & 52.8 & 66.0 & 79.2 & 61.9 & 49.5 & 61.9 & 74.3 \\
\hline $11-20 / 9$ & 64.3 & 51.4 & 64.3 & 77.2 & 60.9 & 48.7 & 60.9 & 73.1 \\
\hline $21-30 / 9$ & 62.7 & 50.2 & 62.7 & 75.2 & 55.4 & 44.3 & 55.4 & 66.5 \\
\hline Total & 193.0 & 154.4 & 193.0 & 231.6 & 178.2 & 142.5 & 178.2 & 213.9 \\
\hline $1-10 / 10$ & 49.6 & 39.7 & 49.6 & 59.5 & 61.5 & 49.2 & 61.5 & 73.8 \\
\hline $11-20 / 10$ & 45.8 & 36.6 & 45.8 & 55.0 & 45.6 & 36.5 & 45.6 & 54.7 \\
\hline $21-30 / 10$ & 46.2 & 37.0 & 46.2 & 55.4 & 37.9 & 30.3 & 37.9 & 45.5 \\
\hline Total & 141.6 & 113.3 & 141.6 & 169.9 & 145.0 & 116.0 & 145.0 & 174.0 \\
\hline
\end{tabular}

$\mathrm{Y}=$ seed yield in $\mathrm{kg} / \mathrm{fed}$.

$\mathrm{CU}=$ seasonal water consumptive use in $\mathrm{cm}$

2.4. Water utilization efficiency (WUtE):

It was calculated according to Jensen (1983).

WUtE $=\frac{\mathrm{Y}}{\text { IWA }}$

Where:

$\mathrm{Y} \quad=$ Seed yield in $\mathrm{kg}$

IWA = Irrigation water applied in $\mathrm{cm}$.

2.5. Soil moisture extraction pattern (SMEP):

It was calculated according to the following equation (Hansen et al., 1979).

Where:

SMEP $=$ CU. (layer) $\times 100 / C U$ (seasonal)

CU. (layer) = sum of extracted soil moisture in each soil layer $(15 \mathrm{~cm})$.

$\mathrm{CU}($ seasonal $)=$ total sum of moisture extracted in all soil layers $(60 \mathrm{~cm})$.

\section{RESULTS AND DISCUSSION}

\subsection{Grain yield and its attributes}

The results in Table (4) show that irrigation scheduling at 1.2 of accumulative pan evaporation (A.P.E.) significantly increased plant height by 4.40 , ear length by $4.6 \%$, number of rows/ear by $16.7 \%$, number of grains/row by $7.4 \%, 100$-grain weight by $6.6 \%$, yield of plant by $17.1 \%$ and grain yield/fed. by $181 \%$ compared to irrigation at 0.8 of
A.P.E. A higher grain yield for irrigated maize cultivars at 1.2 of A.P.E. owing to the higher yield components such as ear length, number of rows/ear, number of grains/row, 100-grain weight, and yield of plant as shown in Table 4. These results are in agreement with those obtained by El-Sabbagh et al. (1997), Abd El-Hafez et al. (2001), Ghadiri and Majidian (2003), Abdel Aziz and El-Bialy (2004), and Galbiatti et al. (2004) who concluded that yield and its attributes of maize plants were gradually increased as a result of increasing in the availability of soil moisture content because the availability of water is an important factor in the growth of maize plants which increase grain yield. Maize is a crop with high production potential when its requirements for growth and reproduction are met (Pierre et al., 1966). The reduction in yield could be attributed to water shortage that causes stomatal closure and this in turn prevent $\mathrm{CO}_{2}$ diffusion into the air inside the tissue of the plants and consequently the photosynthetic efficiency becomes low (Vasic and Videnovic, 1980 and Passioura, 2006).

The data in Table (4) reveal that maize cv. S.C. 10 significantly surpassed cvs. S.C. 122 and S.C. 124 in the mean values of plant height, ear length, number of gains/row, 100-grain weight, yield of plant and gains yield/fed. However, maize 
Table (4): Mean values of yield and its attributes as affected by irrigation and maize cultivars in the combined analysis over both seasons

\begin{tabular}{|l|c|c|c|c|c|c|c|}
\hline \multicolumn{1}{|c|}{ Treatments } & $\begin{array}{c}\text { Plant } \\
\text { height } \\
\text { (cm) }\end{array}$ & $\begin{array}{c}\text { Ear } \\
\text { length } \\
(\mathbf{c m})\end{array}$ & $\begin{array}{c}\text { No. of } \\
\text { rows/ear }\end{array}$ & $\begin{array}{c}\text { No. of } \\
\text { grains/ } \\
\text { row }\end{array}$ & $\begin{array}{c}\text { 100-grain } \\
\text { weight } \\
(\mathbf{g m})\end{array}$ & $\begin{array}{c}\text { yield of } \\
\text { Plant } \\
\text { (gm) }\end{array}$ & $\begin{array}{c}\text { Grain } \\
\text { yield } \\
(\mathbf{k g} / \mathbf{f e d})\end{array}$ \\
\hline Irrigation at: & & & & & & & \\
1.2 of APE & $308 \mathrm{a}$ & $25.2 \mathrm{a}$ & $14.0 \mathrm{a}$ & $45.3 \mathrm{a}$ & $48.42 \mathrm{a}$ & $307.4 \mathrm{a}$ & $4989 \mathrm{a}$ \\
1.0 of APE & $300 \mathrm{~b}$ & $24.6 \mathrm{ab}$ & $12.0 \mathrm{~b}$ & $43.7 \mathrm{~b}$ & $46.72 \mathrm{~b}$ & $284.8 \mathrm{~b}$ & $4605 \mathrm{~b}$ \\
0.8 of APE & $295 \mathrm{c}$ & $24.1 \mathrm{~b}$ & $12.0 \mathrm{~b}$ & $42.2 \mathrm{c}$ & $45.41 \mathrm{c}$ & $262.4 \mathrm{c}$ & $4224 \mathrm{c}$ \\
\hline Maize cultivars: & & & & & & & \\
S.C. 10 & $307 \mathrm{a}$ & $25.2 \mathrm{a}$ & $12.0 \mathrm{~b}$ & $45.3 \mathrm{a}$ & $48.73 \mathrm{a}$ & $319.0 \mathrm{a}$ & $5188 \mathrm{a}$ \\
S.C. 122 & $295 \mathrm{c}$ & $24.3 \mathrm{~b}$ & $14.0 \mathrm{a}$ & $42.2 \mathrm{c}$ & $44.95 \mathrm{c}$ & $256.9 \mathrm{c}$ & $4132 \mathrm{c}$ \\
S.C. 124 & $301 \mathrm{~b}$ & $24.7 \mathrm{~b}$ & $12.0 \mathrm{~b}$ & $43.8 \mathrm{~b}$ & $46.88 \mathrm{~b}$ & $278.5 \mathrm{~b}$ & $4499 \mathrm{~b}$ \\
\hline Interactions: & & & & & & & \\
Irrig. x year & N.S & N.S & N.S & N.S & N.S & N.S & N.S \\
Irrig. x maize cultivars & N.S & N.S & N.S & N.S & N.S & $* *$ & $* *$ \\
Irrig. x maize cultivars x year & N.S & N.S & N.S & N.S & N.S & N.S & N.S \\
\hline
\end{tabular}

Means designated by the same letter at each cell are not significant at the $5 \%$ level according to Duncan's multiple range test. N.S: Indicate not significant

cv. S.C. 122 surpassed maize cvs. S.C. 10 and 124 in the number of rows/ear. These differences may be due to the genetic differences among maize cultivars. The results are in agreement with those obtained by El-Sabbagh (1993), Khalil (2001) Oraby et al.,(2005), Seif et al., (2005), and Neill et al., (2006) and Richards (2006).

Insignificant effect of irrigation and year interaction was obtained on all traits (Table 4). Such results indicate that irrigation treatments showed similar effect from year to year. All the interactions among the two factors studied were not significant except the interactions between irrigation and cultivars on yield of the plant and grain yield/fed.

\section{Interaction between irrigation treatments and maize cultivars}

Data in Table (5) show that the average values of yield of plant and grain yield were significantly affected by the interaction between irrigation scheduling and maize cultivars in the combined analysis over both seasons. It is clear from Table 5 that the highest mean values of yield of the plant and total grain yield were $343.5 \mathrm{gm}$ and 5605 $\mathrm{kg} / \mathrm{fed}$., respectively, obtained from irrigation at 1.2 of A.P.E. with maize cv. S.C. 10. On the other hand, the lowest value of yield of plant and grain yield were $232.5 \mathrm{gm}$ and $3716 \mathrm{~kg} / \mathrm{fed}$., obtained from irrigation at 0.8 of APE using maize cv. S.C. 122. Similar results were reported by Mitu and Zamfir (2004), and El-Atawy (2007) who concluded that low available soil water content resulted in a significant reduction in kernel yield due to disparity in flowering and the frequency of sterile plants.

Reduction percentage in yield of the plant and total grain yield due to irrigation scheduling from
1.2 to 0.8 of A.P.E. was lower with maize cv. S.C. 10 to be 13.0 and $13.6 \%$ respectively, while it was higher with maize cv. S.C. 122 to be 17.2 and $18.1 \%$, respectively, while the reduction in maize cv. S.C. 124 was in between. It was 14.1 and $14.8 \%$ for the yield of plant and total grain yield, respectively. It means that maize cv. S.C. 10 was less affected by water deficit than maize cvs. S.C. 124 and S.C. 122. These results could be attributed to the varietal differences (El-Sabbagh, 1993, Khalil, 2001, Oraby et al., 2005, and Seif et al., 2005).

Table (5): Interaction between irrigation and maize cultivars on yield of the plant and grain yield, over both growing seasons.

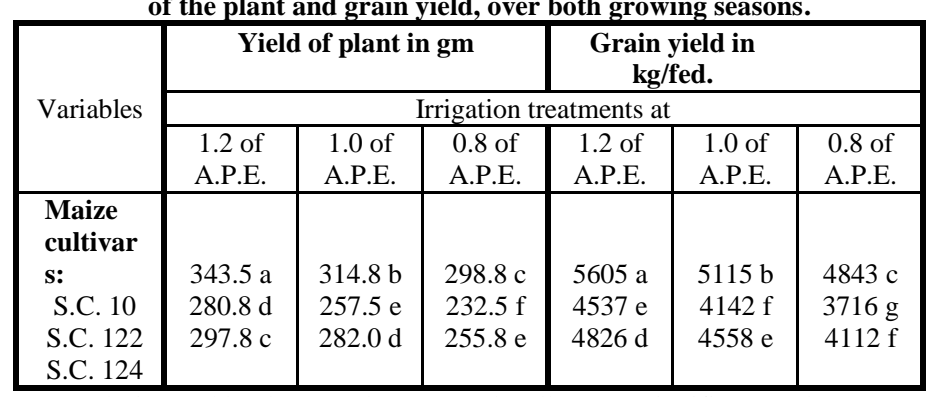

Means designated by the same letter at each cell are not significant at the

\subsection{Soil-water relations}

\subsubsection{Water consumptive use (CU)}

Seasonal rates of water consumption by maize plants under various treatments are presented in Table (6). The results show that seasonal water use values were $57.74,52.16$ and $47.60 \mathrm{~cm}$ for irrigated plants at 1.2, 1.0 and 0.8 of APE, respectively. These results demonstrate that water consumption increased as soil moisture was maintained high by frequent irrigations. The probable explanation of these results is that higher frequent irrigations 
provide chance for more consumption of water which ultimately resulted in increasing transpiration and evaporation from the soil surface.

Monthly water consumptive use value started low at the beginning of maize plant growing season and increased gradually to reach its maximum value in August, as a result of the increase in vegetative growth and higher water consumption by plants, then it declined at maturity. These results indicate that water consumptive use values gradually increased as the available soil moisture increased in the root zone of the plant. These results are confirmed with the data reported by Abd El-Hafez et al., (2001), , Abdel Aziz and El-Bialy (2004), Abdel Mawly and Zanouny (2005) and El-Atawy (2007) and 5 irrigations including seeding irrigation, respectively (Table 7). Seeding and first irrigation were the same for all irrigation treatments. It is obvious that the amount of irrigation water applied was gradually increased as a result of growing up of maize plants that required higher amount of irrigation to meet its water requirements, and then it decreased again. It means that the depth of irrigation water applied was affected by so many factors i.e. growth stages and meteorological variables.

\section{2.1. Frequency and interval of irrigation}

Data in Table 8 show that the means of the interval between two irrigations for 1.2 of A.P.E. were 21 days after seeding, 14 days after the first, 14 days after the second, 13 days after the third,14 days

Table (6): Monthly and seasonal water consumptive use $(\mathrm{cm})$ as affected by irrigation treatments and maize cultivars, over both seasons.

\begin{tabular}{|c|c|c|c|c|c|c|c|}
\hline \multirow{2}{*}{$\begin{array}{c}\text { Irrigation } \\
\text { treatments at }\end{array}$} & \multirow{2}{*}{$\begin{array}{c}\text { Maize } \\
\text { cultivars }\end{array}$} & \multicolumn{5}{|c|}{ Monthly rates $(\mathrm{cm})$} & \multirow{2}{*}{$\begin{array}{c}\text { Seasonal water } \\
\text { consumption }(\mathrm{cm})\end{array}$} \\
\hline & & June & July & August & Sept. & Oct. & \\
\hline \multirow{3}{*}{1.2 of A.P.E. } & S.C. 10 & 2.15 & 12.42 & 21.44 & 17.32 & 4.51 & 57.84 \\
\hline & S.C. 122 & 2.15 & 12.38 & 21.36 & 17.24 & 4.50 & 57.63 \\
\hline & S.C. 124 & 2.15 & 12.40 & 21.41 & 17.29 & 4.50 & 57.75 \\
\hline \multicolumn{2}{|c|}{ Mean } & 2.15 & 12.40 & 21.40 & 17.28 & 4.50 & 57.74 \\
\hline \multirow{3}{*}{1.0 of A.P.E. } & S.C. 10 & 2.15 & 11.88 & 18.73 & 15.22 & 4.33 & 52.31 \\
\hline & S.C. 122 & 2.15 & 11.74 & 18.68 & 15.14 & 4.30 & 52.01 \\
\hline & S.C. 124 & 2.15 & 11.81 & 18.70 & 15.18 & 4.31 & 52.15 \\
\hline \multicolumn{2}{|c|}{ Mean } & 2.15 & 11.81 & 18.70 & 15.18 & 4.31 & 52.16 \\
\hline \multirow{3}{*}{0.8 of A.P.E. } & S.C. 10 & 2.15 & 10.02 & 17.21 & 13.78 & 4.09 & 47.25 \\
\hline & S.C. 122 & 2.15 & 9.96 & 17.11 & 13.54 & 4.02 & 46.78 \\
\hline & S.C. 124 & 2.15 & 9.94 & 17.18 & 13.63 & 4.07 & 46.97 \\
\hline \multicolumn{2}{|c|}{ Mean } & 2.15 & 9.97 & 17.17 & 13.65 & 4.06 & 47.60 \\
\hline \multirow{3}{*}{ Mean of A.P.E. } & S.C. 10 & 2.15 & 11.44 & 19.13 & 15.44 & 4.31 & 52.47 \\
\hline & S.C. 122 & 2.15 & 11.36 & 19.05 & 15.31 & 4.27 & 52.14 \\
\hline & S.C. 124 & 2.15 & 11.38 & 19.10 & 15.37 & 4.29 & 52.29 \\
\hline \multicolumn{2}{|c|}{ Mean } & 2.15 & 11.39 & 19.09 & 15.37 & 4.29 & \\
\hline
\end{tabular}

The data listed in Table (6) indicate that the seasonal amount of water consumed by maize cv. S.C. 10 was slightly higher than maize cvs. S.C. 122 and S.C. 124. This may be attributed to that cv. S.C. 10 has a higher growth and photosynthetic activity more than other cultivars.

\subsubsection{Irrigation water applied (IWA):}

Amount of irrigation water applied was calculated by summation of daily evaporation records from class A pan evaporation for each treatment. Results in Table 7 indicate that watering at 1.2 of A.P.E. resulted in higher amount of irrigation water applied to be $74.3 \mathrm{~cm}$ (3120.6 $\mathrm{m}^{3} /$ fed.) due to frequent irrigation, followed by watering at 1.0 and 0.8 of APE to be $67.2 \mathrm{~cm}$ (2822.4 $\mathrm{m}^{3} /$ fed.) and $57.1 \mathrm{~cm}\left(2398.2 \mathrm{~m}^{3} /\right.$ fed.), respectively. Amount of irrigation water applied at $1.2,1.0$ and 0.8 of A.P.E. was distributed on 7,6
Table (7):Seasonal water applied (cm) as affected by irrigation treatments, over both seasons.

\begin{tabular}{|c|c|c|c|}
\hline \multirow{2}{*}{ No. of irrigation } & \multicolumn{3}{|c|}{ Irrigation treatments at } \\
\cline { 2 - 4 } & 1.2 of & 1.0 of & 0.8 of \\
& A.P.E. & A.P.E. & A.P.E. \\
\hline Seeding irrigation & 10.8 & 10.8 & 10.8 \\
$1^{\text {st }}$ & 7.9 & 7.9 & 7.9 \\
$2^{\text {nd }}$ & 9.5 & 10.8 & 13.6 \\
$3^{\text {rd }}$ & 12.0 & 15.5 & 13.0 \\
$4^{\text {th }}$ & 14.5 & 12.9 & 11.8 \\
$5^{\text {th }}$ & 10.6 & 9.3 & \\
$6^{\text {th }}$ & 9.0 & & \\
\hline Total & $74.3 \mathrm{~cm}$ & $67.2 \mathrm{~cm}$ & $57.1 \mathrm{~cm}$ \\
& $(3120.6$ & $(2822.4$ & $(2398.2$ \\
& $\left.\mathrm{m}^{3} / \mathrm{fed}.\right)$ & $\left.\mathrm{m}^{3} / \mathrm{fed}.\right)$ & $\left.\mathrm{m}^{3} / \mathrm{fed}.\right)$ \\
\hline
\end{tabular}

after fourth and 16 after the fifth. While irrigation the intervals for 1.0 of A.P.E. were 21 after seeding, 16 days after the first, 18 days after the second and the third, and 19 days after the fourth, however, irrigation intervals for treatments irrigated at 0.8 of 


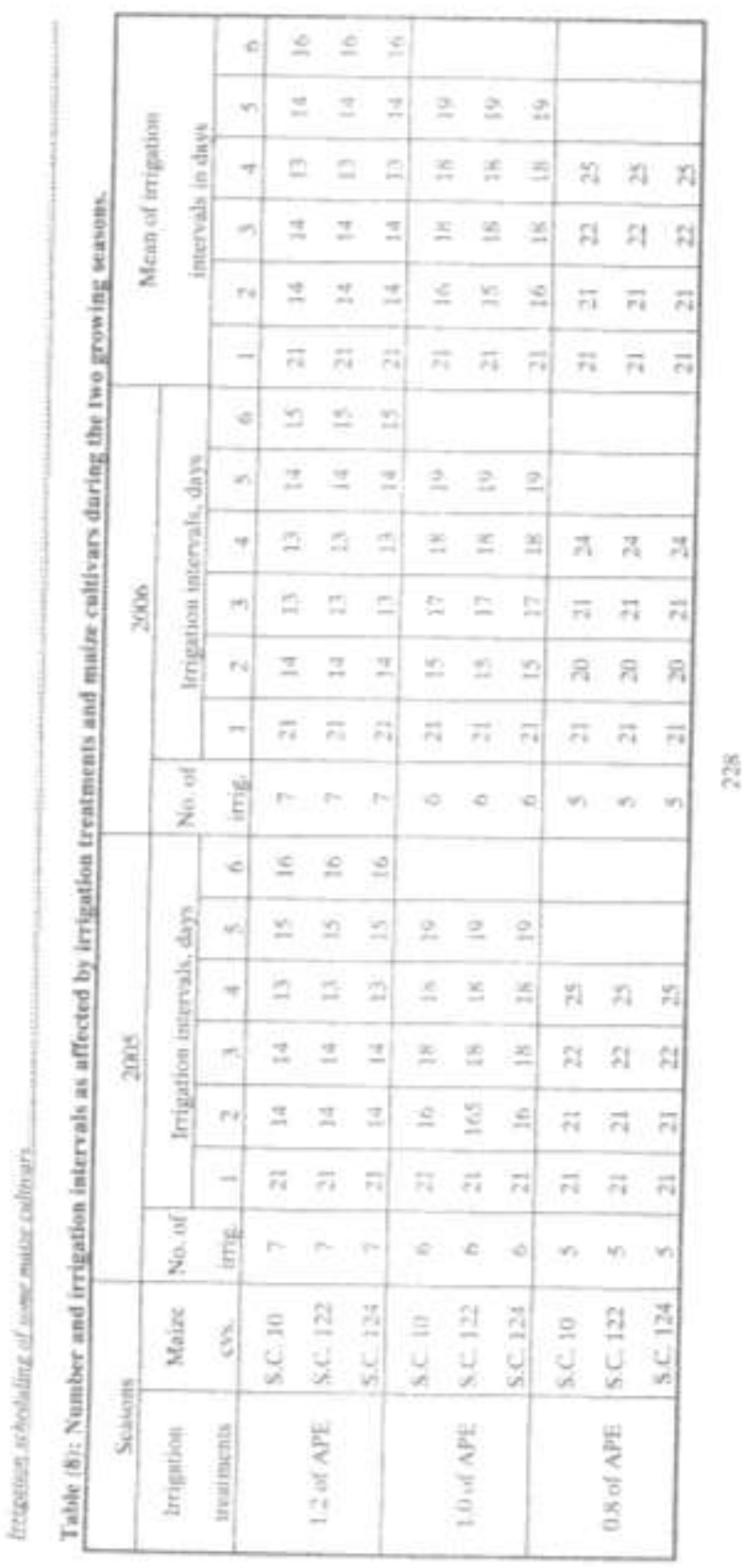


A.P.E. were 21 days after seedling, 21 days after the first and 22 days after the second, and 25 days after the third. It means that the frequency of irrigation and interval of irrigation are closely related and are often interchangeable (Majumdar, 2002).

\section{2.3. Water use efficiency (WUE)}

Water use efficiency expressed in $\mathrm{kg}$ of grain yield/cm of water consumed is preened in Table (9). Results obtained show that WUE increased as the soil moisture deficit increased. Maize cultivars irrigated at 0.8 of A.P.E. had the highest value of WUE to be $89.83 \mathrm{~kg}$ of grain yield $/ \mathrm{cm}$ of water consumed, while the lowest one was $85.73 \mathrm{~kg}$ of grain yield/cm of water consumed, resulted from watering at 1.2 of A.P.E. These findings could be attributed to the highly significant differences among grain maize yield as well as differences between water consumptive use. The present results are in line with those reported by Ghadiri and Majidian (2003), Abdel Mawly and Zanouny (2005), Yang et al., (2005) and El-Atawy (2007), who mentioned that the efficiency of water use decreased as the soil moisture was maintained high by frequent irrigation.

Concerning maize cultivars, Table (9) shows that maize cv. S.C. 10 significantly increased WUE by 24.97 and $16.76 \%$ compared to maize cvs. S.C. 122 and S.C. 124 respectively. It attributed to higher grain yield for maize cv. S.C. 10 than the other cultivars. In this respect, Yang et al.,(2005) indicated that water use efficiency significantly varied among the cultivars. Results in Table 10 show that the highest WUE was $102.50 \mathrm{~kg}$ grain yield $/ \mathrm{cm}$ of water consumed, resulted from irrigation at 0.8 of A.P.E. using maize cv. S.C. 10 while the lowest one was $78.73 \mathrm{~kg}$ seed yield $/ \mathrm{cm}$ of water consumed, resulted from irrigation at 1.2 of APE using maize cv. S.C. 122.

\subsubsection{Water utilization efficiency (WUtE)}

Mean values of water utilization efficiency as affected by irrigation scheduling and maize cultivars are shown in Table 10. Results indicate that the highest values of WUtE were recorded from the irrigation at 0.8 of APE whereas the lowest ones were obtained from irrigation at 1.2 of APE. These results could be attributed to the significant differences among maize grain yield, evapotranspiration and water applied values.

Data in Table 10 reveal that maize cv. S.C. 10 significantly increased WUtE by 25.89 and $15.42 \%$ than maize cvs. S.C. 122 and S.C. 1234, respectively. Data illustrated in Table 11 indicate that irrigation scheduling at 0.8 of A.P.E. with maize cv. S.C. 10 produced the highest WUtE to be
$84.85 \mathrm{~kg}$ grain yield $/ \mathrm{cm}$ of water applied but the lowest value resulted from irrigation scheduling at 1.2 of A.P.E. using maize cv. S.C. 122 to be 61.07 $\mathrm{kg}$ grain yield/cm of water applied.

Table (9):Average water use efficiency ( $\mathrm{kg}$ grain yield/cm of water consumed) as affected by irrigation and maize cultivars, over both growing seasons.

\begin{tabular}{|l|c|c|c|c|}
\hline \multirow{2}{*}{ Variables } & \multicolumn{3}{|c|}{ Irrigation treatments at } & \multirow{2}{*}{ Mean } \\
\cline { 2 - 4 } & 1.2 of & 1.0 of & 0.8 of & \\
& A.P.E & A.P.E & A.P.E & \\
\hline Maize cultivars: & & & & \\
S.C. 10 & $96.90 \mathrm{~b}$ & $97.79 \mathrm{~b}$ & $102.50 \mathrm{a}$ & $99.06 \mathrm{~A}$ \\
S.C. 122 & $78.73 \mathrm{e}$ & $79.63 \mathrm{e}$ & $79.44 \mathrm{e}$ & $79.27 \mathrm{C}$ \\
S.C. 124 & $81.57 \mathrm{~d}$ & $85.41 \mathrm{c}$ & $87.54 \mathrm{c}$ & $84.84 \mathrm{~B}$ \\
\hline Mean & $85.73 \mathrm{C}$ & $87.61 \mathrm{~B}$ & $89.83 \mathrm{~A}$ & \\
\hline
\end{tabular}

Means designated by the same letter at each cell are not significant at the 5\% level according to Duncan's multiple range test.

Table (10): Average water utilization efficiency (kg grain yield/cm of irrigation water applied) as affected by irrigation and maize cultivars, over both growing seasons.

\begin{tabular}{|c|c|c|c|c|}
\hline \multirow[t]{2}{*}{ Variables } & \multicolumn{3}{|c|}{ Irrigation treatments at } & \multirow[t]{2}{*}{ Mean } \\
\hline & $\begin{array}{l}1.2 \text { of } \\
\text { A.P.E }\end{array}$ & $\begin{array}{l}1.0 \text { of } \\
\text { A.P.E }\end{array}$ & $\begin{array}{l}0.8 \text { of } \\
\text { A.P.E }\end{array}$ & \\
\hline Maize cultivars: & & & & \\
\hline S.C. 10 & $75.43 \mathrm{c}$ & $76.20 \mathrm{~b}$ & $84.85 \mathrm{a}$ & $78.83 \mathrm{~A}$ \\
\hline S.C. 122 & $61.07 \mathrm{~h}$ & $61.70 \mathrm{~h}$ & $65.11 \mathrm{f}$ & $62.62 \mathrm{C}$ \\
\hline S.C. 124 & $64.96 \mathrm{~g}$ & $67.90 \mathrm{e}$ & $72.04 \mathrm{~d}$ & $68.30 \mathrm{~B}$ \\
\hline Mean & $67.15 \mathrm{C}$ & $68.60 \mathrm{~B}$ & $74.00 \mathrm{~A}$ & \\
\hline
\end{tabular}

Means designated by the same letter at each cell are not significant at the 5\% level according to Duncan's multiple

\subsubsection{Soil moisture extraction pattern (SMEP)}

Data of soil moisture extraction percentage in the upper $60 \mathrm{~cm}$ of soil depth are presented in Table 11. It can be observed that most of the water consumed by maize cultivars was removed from the upper $30 \mathrm{~cm}$. Data indicate that maize cultivars extracted about $76.14,71.22$ and $64.24 \%$ soil water from $0-30 \mathrm{~cm}$ soil layer for irrigation scheduling at $1.2,1.0$ and 0.8 of A.P.E., respectively. However, the remainder values were $23.86,28.78$ and $35.76 \%$ withdrawn from the lower $30-60 \mathrm{~cm}$. These values show that when the soil is kept wet due to multiple irrigation, more water is extracted from the upper $30 \mathrm{~cm}$ soil layer. On the other hand, when soil moisture content of the surface layers were subjected to water deficit, as a result of irrigation scheduling at 0.8 of A.P.E., maize plants tended to extract its water requirements from deeper soil layers. These findings could be attributed to the fact that most maize plants roots are concentrated in the upper soil layers and those roots are the most effective in water extraction. Similar results were found by Chimenti et al.,(2006) who showed that 
crops extracted significant more water from deeper in the soil profile during the stress period.

As for maize cultivars, data in Table (11) show no effect on this trait, and the values were about the same.

Table (11): Percentage of soil moisture extraction by roots for different layers as affected by irrigation treatments and maize cultivars, over both seasons.

\begin{tabular}{|c|c|c|c|c|c|c|c|}
\hline \multirow{2}{*}{\begin{tabular}{|c|} 
Irrigat \\
ion \\
treatm \\
ents
\end{tabular}} & \multirow[t]{2}{*}{$\begin{array}{c}\text { Maize } \\
\text { cultivars }\end{array}$} & \multicolumn{4}{|c|}{$\begin{array}{l}\text { Percentage of soil moisture } \\
\text { extraction in different soil } \\
\text { depths }(\mathrm{cm})\end{array}$} & \multicolumn{2}{|c|}{ Mean of SMEP } \\
\hline & & $0-15$ & $15-30$ & $30-45$ & $45-60$ & $0-30$ & $30-60$ \\
\hline & S.C. 10 & 50.81 & 25.87 & 18.10 & 5.22 & 76.68 & 23.32 \\
\hline 1.2 of & S.C. 122 & 50.59 & 25.11 & 17.88 & 6.42 & 75.70 & 24.30 \\
\hline A.P.E. & S.C. 124 & 50.73 & 25.31 & 18.05 & 5.91 & 76.04 & 23.96 \\
\hline \multicolumn{2}{|c|}{ Mean } & 50.71 & 25.43 & 18.01 & 5.85 & 76.14 & 23.86 \\
\hline & S.C. 10 & 45.70 & 25.91 & 19.50 & 8.89 & 71.61 & 28.39 \\
\hline 1.0 of & S.C. 122 & 45.51 & 25.33 & 18.96 & 10.20 & 70.84 & 29.16 \\
\hline A.P.E. & S.C. 124 & 45.66 & 25.54 & 19.45 & 9.35 & 71.22 & 28.78 \\
\hline \multicolumn{2}{|c|}{ Mean } & 45.62 & 25.59 & 19.30 & 9.48 & 71.22 & 28.78 \\
\hline & S.C. 10 & 38.61 & 25.98 & 21.35 & 14.06 & 64.59 & 35.41 \\
\hline 0.8 of & S.C. 122 & 38.42 & 25.47 & 21.20 & 14.91 & 63.89 & 36.11 \\
\hline & S.C. 124 & 38.54 & 25.70 & 21.31 & 14.45 & 64.24 & 35.76 \\
\hline \multicolumn{2}{|c|}{ Mean } & 38.52 & 25.72 & 21.29 & 14.47 & 64.24 & 35.76 \\
\hline \multirow{4}{*}{$\begin{array}{c}\begin{array}{c}\text { Mean } \\
\text { of } \\
\text { A.P.E. }\end{array} \\
\text { N }\end{array}$} & S.C. 10 & 45.04 & 25.92 & 19.65 & 9.39 & 70.96 & 29.04 \\
\hline & S.C. 122 & 44.84 & 25.30 & 19.35 & 10.51 & 70.14 & 29.86 \\
\hline & S.C. 124 & 44.96 & 25.52 & 19.60 & 9.90 & 70.48 & 29.52 \\
\hline & Mean & 44.95 & 25.58 & 19.53 & 9.93 & 70.53 & 29.47 \\
\hline
\end{tabular}

\subsubsection{Regression slopes and correlation coefficients}

A linear equation is presented in Table 12 indicates that each one $\mathrm{cm}$ of water applied increased the productivity by $44.0 \mathrm{~kg} / \mathrm{fed}$. as shown in (Eq. [1]). However, each one $\mathrm{cm}$ of water applied decreased water use efficiency (WUE) by $0.20 \mathrm{~kg}$ grain/cm of water consumed (Eq. [2]) and decreased water utilization efficiency (WUtE) by $0.41 \mathrm{~kg} / \mathrm{cm}$ of water applied (Eq. [3]). Irrigation water applied is strongly positively correlated with grain yield (Omran, 2005) and negatively to water use efficiencies as shown in Table 12.

This means that perfect irrigation water

Table(12): Regression slopes and correlation coefficients between irrigation water applied (IWA) and grain yield (GY), water use efficiency (WUE) and water utilization efficiency (WUtE).

\begin{tabular}{|c|c|c|}
\hline Variables & Equation & $\begin{array}{c}\text { Correlation } \\
\text { (r) }\end{array}$ \\
\hline $\begin{array}{c}\text { Grain yield } \\
\text { in kg/fed. }\end{array}$ & $\mathrm{GY}=1692+44.0$ (IWA)....(1) & 0.78 \\
\hline $\begin{array}{c}\text { Water use } \\
\text { efficiency }\end{array}$ & $\mathrm{WUE}=101-0.20$ (IWA) .....(2) & -0.70 \\
\hline $\begin{array}{c}\text { Water } \\
\text { utilization } \\
\text { efficiency }\end{array}$ & WUtE $=97-0.41$ (IWA) ......(3) & -0.68 \\
\hline
\end{tabular}

requirements are a necessity to develop a large plant canopy which increases the maize productivity. However, water use efficiencies were reduced as a result of frequent irrigation. This result could be attributed to a large fraction of irrigation water applied to the soil that are lost either through leaching, evaporation, or both.

\section{REFERENCES}

Abd El-Hafez S.A., El-Sabbagh A.A., El-Bably A.Z. and Abo-Ahmed E.I. (2001). Response of maize crop to drip irrigation in clay soils. Alex. J. Agric. Res. Egypt, 46 (2): 153-159.

Abdel-Aziz A. and El-Bialy U.S. (2004). Response of maize plant to soil moisture stress and foliar spray with potassium. J. Agric. Sci. Mansoura Univ., Egypt, 29(6): 3599-3619.

Abdel Mawly S.E. and Zanouny I. (2005). Irrigation and fertilization management for maximizing crop-water efficiencies of maize. Minia. J. Agric. Res. \& Develop., Egypt, 25 (1): 125-146.

Chimenti C.A., Marcantono M. and Hall A.J. (2006). Divergent selection for osmotic adjustment results in improved drought tolerance in maize (Zea mays L.) in both early growth and flowering phases. Field Crops Research, 95(2/3): 305-315.

Duncan B.D. (1955). Multiple range and multiple Ftest. Biometri, 11: 1-42.

El-Atawy E.E.I. (2007). Irrigation and Fertilization Management Under the Conditions of Kafr El-Sheikh Governorate Soil. Ph.D. Thesis, Soil Dept. Fac. of Agric., Mansoura Univ., Egypt.

El-Sabbagh A.A. (1993). Effect of Soil Moisture Stress and Foliar Application of Zinc on Some Maize Varieties. Ph.D. Thesis, Agron. Dept., Fac. of Agric., Zagazig Univ., Egypt.

El-Sabbagh A.A., Abd El-Hafez S.A. and AbouAhmed E.I. (1997). Response of some maize cultivars to water regime. Menofiya J. Agric. Res., Egypt, 22(5): 1431-1440.

Galbiatti J.A., Borges M.J., Bueno L.F., Garcia A. and Vieira R.D. (2004). Effect of different irrigation periods in the development, yield and seedling quality in the maize (Zea mays L.) crop. Engenharia Agricola 24 (2): 301-308.

Ghadiri H. and Majidian M. (2003). Effect of different nitrogen fertilizer levels and moisture stress during milky and dough stages on grain yield, yield components and water use efficiency of corn (Zea mays L.). Journal of Science and Technology of Agriculture and Natural resources. 7(2): 103-113.

Hansen V.W., Israelsen D.W. and Stringharm Q.E. (1979). Irrigation Principle and Practices, $4^{\text {th }}$ ed. John Wiley \& Sons., New York. 
Ibrahim A.M., Seif El-Yazal S.A. and El-Sayim R.G. (2005). Response of maize vegetative growth and yield to partial N-mineral replacement by biological nitrogen fixation under different soil moisture stresses. J. Agric. Sci. Mansoura Univ., Egypt, 30(4): 2259-2273.

Jensen M.E. (1983). Design and Operation of Farm Irrigations Systems. Amer.Soc. Agric. Eng. Michigan, USA.

Kamara A.Y., Badu A. and Ibikunle O. (2003). The influence of drought stress on growth, yield and yield components of selected maize genotypes. Journal of Agricultural Science, 141(1): 43-50.

Kefale D. and Ranamukhaarachchi S.L. (2004). Response of maize varieties to drought stress at different phenological stages in Ethiopia. Tropical Science 44(2): 61-66.

Khalil F.A.F. (2001). Scheduling Irrigation of Maize by Using the Evaporation Pan Method. Ph.D. Thesis, Fac. of Agric. Moshtohor, Zagazig Univ., Benha Branch. Egypt.

Klute A. (1986). Methods of Soil Analysis. Part 1. $2^{\text {nd }}$ ed. ASA and SSSA. Madison, Wisconsin, USA.

Mahfouz H. (2003). Productivity of ten maize hybrids under water stress conditions. Egypt. J. Appl. Sci. 18(12): 189-206.

Majumdar D.K. (2002). Irrigation Water Management, Principles and Practice. PrenticeHall of India Privet Limited, New Delhi, India, p. 261-283.

Michael A.M. (1978). Irrigation Theory and Practice. Vikas Publishing House PVT LTD New Delhi, Bombay.

Ministry of Agriculture (2005). Cultivation of maize in the old lands. The central Administration for the Agricultural Extension. Bulletin No. 961. p. 5-20.

Mitu D. and Zamfir M.C. (2004). Behavior of some maize hybrids under drought conditions, Analel Institutului de Cerecetari pentru Cereale si Plante Tehnice, Fundulea, 71: 137-148.

Neill P.M., Shanahan J.F. and Schepers J.S. (2006). Use of chlorophyll fluorescence assessments to differentiate corn hybrid response to variable water conditions. Crop Science. 46(2): 681-687.

Omran W.M. (2005). Maize yield response to available soil moisture. Minufiya. J. Agric., Res., Egypt, 30(4): 1257-1268.

Oraby F.T., Omar A.E.A., Abd El-Maksoud M.F. and Sarhan A.A. (2005). Proper agronomic practices required to maximize productivity of maize varieties in old and reclaimed soils. $\mathrm{J}$. Agric. Sci., Mansoura Univ., Egypt, 30(4): 1839-1850.

Page A.L. (ed.) (1982). Methods of Soil Analysis. Part 2. $2^{\text {nd }}$ ed. ASA and SSSA, Madison, Wisconsin, USA.

Passioura J. (2006). Increasing crop productivity when water is scarce from breeding to field management. Agricultural water management 80(1/3): 176-196.

Pierre W.H., Aldrich S.R. and Martin W.P. (1966). Advances in Corn Production, Principles and Practices. Ames, Iowa State University Press. 467pp.

Richards R.A. (2006). Physiological traits used in the breeding of new cultivars for water scarce environments. Agricultural Water Management 80(1/3): 197-211.

Seif S.A., Allam S.A.H., El-Emery M.E. and El-Galfy A.E.M. (2005). Effect of soil moisture depletion on growth, yield and yield components of some maize varieties. Annals of Agricultural Science, Moshtohor, 43(1): 25-38.

Snedecor G.W. and Cochran W.G.(1980). Statistical Methods $7^{\text {th }}$ edition, Iowa State Univ. Press, Ames, Iowa, USA.

Vasic G. and Videnovic Z. (1980). The role of water and fertilizer in field formation of maize. (C.F. Field Crop Abst, 34(1): 5299, 1981).

Yang T., Liang Z.S., Xue J. and Kang S. (2005). Diversity of water use efficiency in various maize varieties. Transaction of the Chinese Society of Agricultural Engineering. 21(10): 21-25. 
جدولة رى بعض أصناف الذرة الثامية باستخدام وعاء البخر القياسى فى شمال الالتا بمصر

\author{
علاء زهير البابلى مئى \\ معهد بحوث الار اضى و المياه والبيئة ـ مركز البحوث الزيلم الزية ـ الجيزه ـ مصر \\ ملخص
}

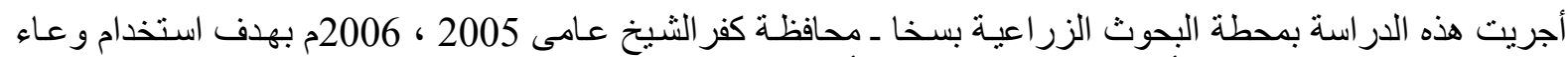

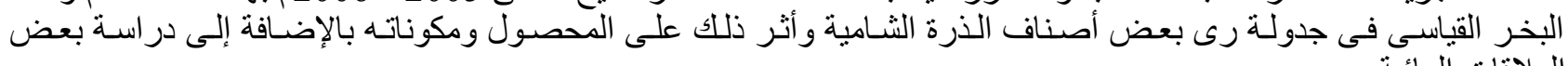

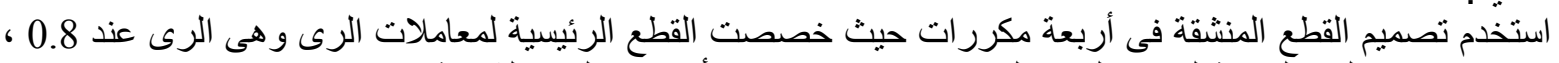
العلاقات المائية.

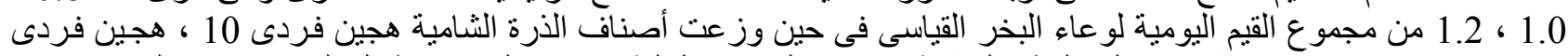

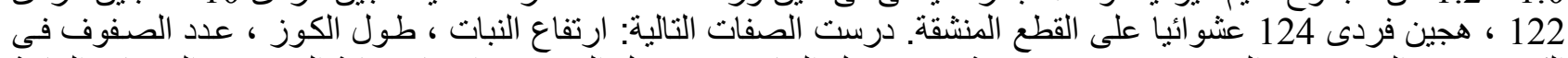

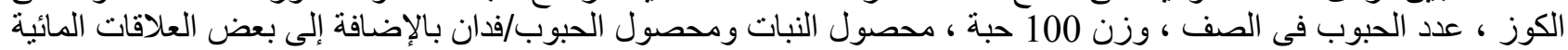
. توصلت الدر اسة إلى النتائج التنالية:

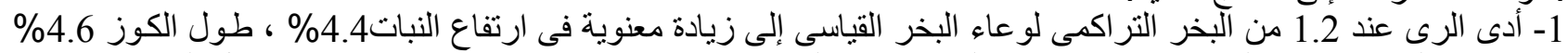

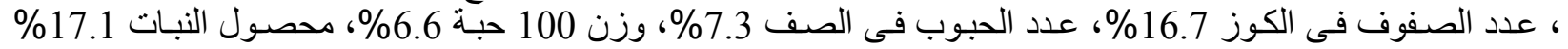

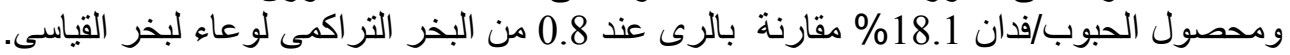

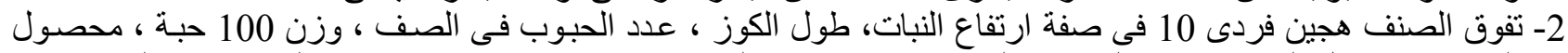

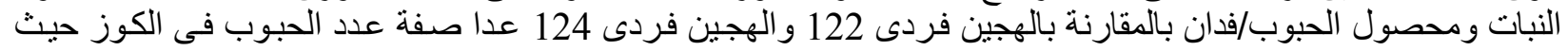

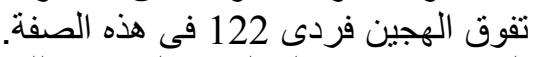

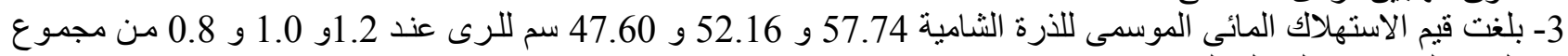

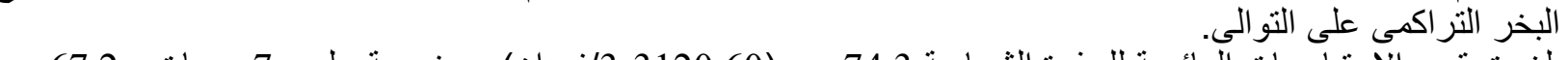

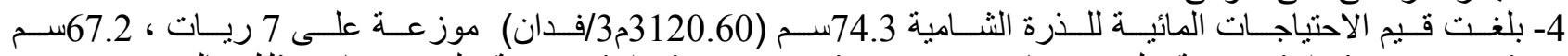

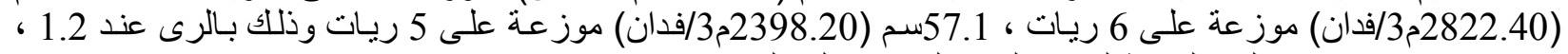

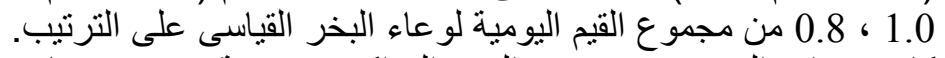

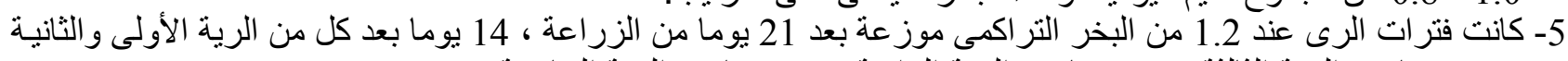

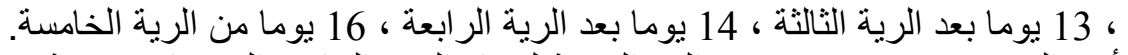

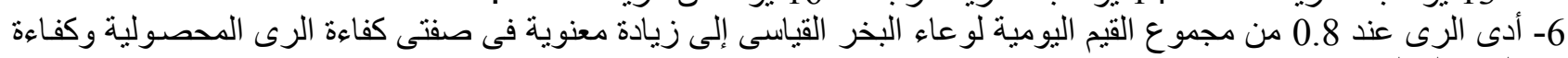

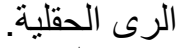

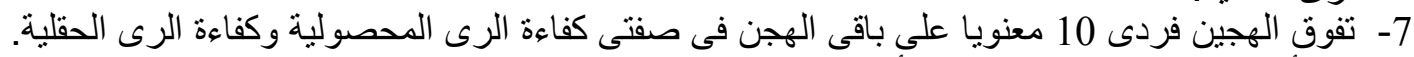

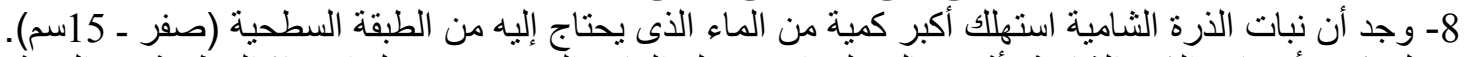

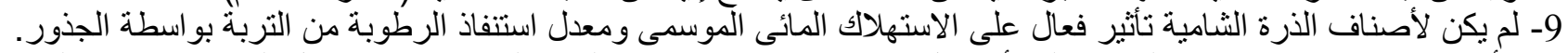

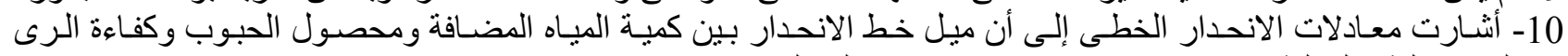

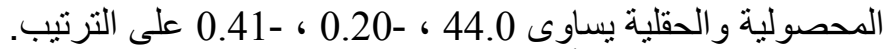

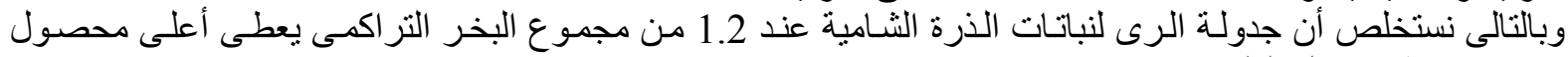

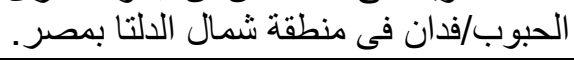
المجلة العلمية لكلية الزر اعة - جامعة القاهرة - المجلد(58) العدد الثالث (يوليو 2007):2232-232. 